\title{
Mineral concentration dynamics among 7 northern Great Basin grasses
}

\author{
DAVE GANSKOPP AND DAVE BOHNERT
}

Authors are Rangeland Scientist, USDA-ARS, Eastern Oregon Agricultural Research Center ${ }^{1}$, 67826-A Hwy. 205, Burns, Ore. 97720; and Range Animal Nutritionist, Oregon State University, E.O.A.R.C., 67826-A Hwy. 205, Burns, Ore. 97720.

${ }^{I}$ The Eastern Oregon Agricultural Research Center is jointly operated by the USDA-Agricultural Research Service and the Oregon Agr. Exp. Sta. of Oregon State University.

\section{Abstract}

Livestock and wildlife managers must be aware of the nutritional dynamics of forages to sustain satisfactory growth and reproduction of their animals and assure fair value for pasture. Despite a history of livestock grazing in the northern Great Basin, annual and seasonal mineral concentrations of many of the region's prominent grasses have not been measured. We addressed this problem with monthly sampling (April-November) of 7 cool-season grasses at 6 sites during 1992, a drier than average year (86\% of mean precipitation), and 1993 when precipitation was $167 \%$ of average $(255 \mathrm{~mm})$. Grasses included: Poa sandbergii Vasey, Bromus tectorum L., Sitanion hystrix (Nutt.) Smith, Agropyron spicatum (Pursh) Scribn. \& Smith, Festuca idahoensis Elmer, Stipa thurberiana Piper, and Elymus cinereus Scribn. \& Merr. Phosphorus, $\mathrm{K}, \mathrm{Ca}, \mathrm{Mg}, \mathrm{Mn}, \mathrm{Fe}, \mathrm{Cu}, \mathrm{Zn}$, and $\mathrm{Na}$ were assayed, and initial statistical analysis was a split-split-plot with main effects of species, years, and months and all possible interactions. For a preponderance of the minerals, ( $\mathrm{Zn}$ and $\mathrm{Na}$ excluded) the 3-way year $x$ month $x$ species interactions were significant $(P<0.05)$ indicating that main effects did not function independently. Generally, mineral concentrations averaged about $\mathbf{4 1 \%}$ higher among the grasses for the drier of the 2 years (1992). Copper, $\mathrm{Zn}$, and $\mathrm{Na}$ concentrations were below required levels for beef cattle $\left(9.9,28.8\right.$, and $672 \mathrm{mg} \mathrm{kg}^{-1}$, respectively) among all the grasses for all sampling periods. Seasonally deficient minerals included $\mathrm{Ca}, \mathrm{Mg}, \mathrm{P}, \mathrm{K}$, and $\mathrm{Mn}$. Calcium and $\mathrm{Mn}$ were largely deficient $\left(<3.2\right.$ and $1.15 \mathrm{~g} \mathrm{~kg}^{-1}$, respectively) for beef cattle early in the growing season with levels rising as grasses matured. Seasonal patterns of $\mathrm{Mg}$ were variable among the grasses, increasing in some as the season progressed, remaining stable among others, and declining with maturity in yet others. Phosphorus and $K$ levels were typically adequate ( $>1.94$ and 5.76 $\mathrm{g} \mathrm{kg}^{-1}$, respectively) for beef cattle early in the growing season and declined to deficient levels by July and August. Iron was of no concern, because concentrations were more than adequate for cattle ( $\left.>48 \mathrm{mg} \mathrm{kg}^{-1}\right)$ among all the grasses for all seasons. While a mixed stand of forages can extend the period of adequate mineral nutrition for cattle in some instances, we suggest that a supplement be available season-long on northern Great Basin rangelands and that the formulation include at least $\mathrm{Ca}, \mathrm{Mg}, \mathrm{P}, \mathrm{K}, \mathrm{Cu}$, $\mathrm{Zn}, \mathrm{Mn}$, and $\mathrm{Na}$ in available forms and proper ratios.

Technical Paper No. 11899 Oregon Agr. Exp. Sta.

Manuscript accepted 16 May 02.
Resumen

Los manejadores de fauna y ganado deben estar enterados de las dinámicas nutricionales de los forrajes para sostener un crecimiento y reproducción satisfactorios de sus animales y asegurar el valor favorable de sus praderas. A pesar del historial de apacentamiento de ganado en la Gran Cuenca del Norte las concentraciones anuales y estaciónales de minerales de muchos de los zacates importantes de esta región no habían sido medidas. Nosotros abordamos este problema con muestreos mensuales (Abril - Noviembre) de 7 zacates de estación fría en 6 sitios, durante 1992, un año mas seco que el promedio (86\% de la precipitación promedio) y en 1993 cuando la precipitación fue $167 \%$ de la precipitación promedio $(255 \mathrm{~mm})$. Los zacates muestreados fueron: Poa sandbergii Vasey, Bromus tectorum L., Sitanion hystrix (Nutt.) Smith, Agropyron spicatum (Pursh) Scribn. \& Smith, Festuca idahoensis Elmer, Stipa thurberiana Piper, and Elymus cinereus Scribn. \& Merr. y los minerales determinados fueron $\mathbf{P}$, $\mathrm{K}, \mathrm{Ca}, \mathrm{Mg}, \mathrm{Mn}, \mathrm{Fe}, \mathrm{Cu}, \mathrm{Zn}$ y $\mathrm{Na}$. El análisis estadístico inicial fue un diseño experimental de parcelas subdivididas, en el que los efectos principales fueron las especies, años y meses y todas sus posibles interacciones. Para la mayoría de los minerales (excluyendo $\mathrm{Zn}$ y $\mathrm{Na}$ ) las interacciones triples año $x$ mes $x$ especie fueron significativas $(p<0.05)$ indicando que los efectos principales no actúan en forma independiente. Generalmente las concentraciones de minerales promediaron aproximadamente $41 \%$ mas en los zacates del año mas seco (1992). Las concentraciones de $\mathrm{Cu}, \mathrm{Zn}$ y Na estuvieron por abajo de los niveles requeridos por el ganado para carne $\left(9.9,28.8\right.$ y $672 \mathrm{mg} \mathrm{kg}^{-1}$, respectivamente), esto fue para todos los zacates y todos los periodos de muestreo. Los minerales estacionalmente deficientes incluyeron al $\mathrm{Ca}, \mathrm{Mg}, \mathrm{P}, \mathrm{K}$ y $\mathrm{Mn}$. El Ca y Mn fueron muy deficientes $\left(<3.2\right.$ y $1.15 \mathrm{~g} \mathrm{~kg}^{-1}$, respectivamente) para el ganado para carne al inicio de la estación de crecimiento y los niveles fueron incrementando conforme los zacates maduraron. Los patrones estaciónales de $\mathrm{Mg}$ variaron entre las especies de zacates, incrementando en algunos de ellos conforme la estación de crecimiento avanzó, permaneciendo estable en otros y disminuyendo con la madurez en otros. Al inicio de le estación de crecimiento los niveles de $\mathbf{P}$ y $\mathbf{K}$ fueron adecuados ( $>1.94$ y $5.76 \mathrm{~g} \mathrm{~kg}^{-1}$, respectivamente) para el ganado para carne y disminuyeron a niveles deficientes en Julio y Agosto. Respecto al Fe no hubo preocupación porque las con centraciones fueron más que adecuadas para le ganado ( $>48 \mathrm{mg}$ $\mathrm{kg}^{-1}$ ), esto fue para todas las especies y todas las estaciones. Mientras que en algunas situaciones una comunidad con 
diversas especies forrajeras puede extender el periodo de una nutrición adecuada de minerales para el ganado, nosotros sugerimos que en los pastizales de la Gran Cuenca del norte se tenga una suplementación de minerales disponible durante toda la estación y que la formulación incluya al menos $\mathrm{Ca}, \mathrm{Mg}, \mathrm{P}, \mathrm{K}, \mathrm{Cu}$, $\mathrm{Zn}$, Mn y Na en formas disponibles y relaciones adecuadas.

Key Words: copper, zinc, manganese, sodium, iron, phosphorus, magnesium, potassium, calcium, Poa sandbergii, Bromus tectorum, Sitanion hystrix, Agropyron spicatum, Festuca idahoensis, Stipa thurberiana, Elymus cinereus

Stockmen and wildlife managers must be aware of the nutritional concentrations of forages on rangelands to assure adequate growth and reproduction of their animals and make informed decisions when purchasing supplements. Similarly, those marketing pasture should also be aware of the nutritional characteristics of their forages to assure reasonable and fair returns. Despite a history of livestock grazing in the northern Great Basin, there have been few efforts to quantify the seasonal and annual mineral concentrations of the region's most prominent rangeland grasses (Murray et al. 1978, Mayland and Shewmaker 1997).

The northern Great Basin experiences an arid Mediterranean climate with about $80 \%$ of the annual precipitation occurring in the fall, winter, and spring months when low temperatures hinder plant growth. Rangeland grasses typically begin growth with warming temperatures in the spring, and herbage accumulation stops upon depletion of soil moisture in mid- to lateJuly (Sneva 1982, Ganskopp 1988). Hickman (1975) presented Ca and P profiles for 4 grasses common to the region, and Murray et al. (1978) and Mayland and Shewmaker (1997) described the seasonal dynamics of 9 elements for 2 introduced and 5 native grasses in southern Idaho. Neither source, however, addressed the year to year disparities in nutritive value associated with precipitation differences.

Rates of gain for livestock reflect the nutritional dynamics of the region's forages with mature cows gaining up to 1.86 $\mathrm{kg} \mathrm{day}{ }^{-1}$ early in the growing season and losing $0.4 \mathrm{~kg} \mathrm{day}^{-1}$ by mid- to late-August (Raleigh and Wallace 1965, Turner and DelCurto 1991). Within the same period, calf gains may range from 0.7 to as little as $0.1 \mathrm{~kg} \mathrm{day}^{-1}$ (Turner and DelCurto 1991). Mineral supplementation has not been intensively studied in this region, however, Murray et al. (1978) reported enhanced April-December gains in cattle supplemented with protein, phosphorus, and sulfur and slightly elevated gains of supplemented calves from August to December. Later, Mayland et al (1980) documented increased weight gains by grazing cattle supplemented with additional zinc.

Our objective was to characterize seasonal and annual mineral concentrations of 7 of the region's most prominent rangeland grasses. This was accomplished via monthly sampling at 6 sites during 1992, a drier than average year, and 1993 when above average precipitation occurred.

\section{Materials and Methods}

Six collection sites were identified near Burns, Ore. with each supporting a broad array of forages. Specific locations, elevations, and soil classifications for each site were reported by Ganskopp and Bohnert (2001). Among the 6 sites, mean soil depth was $69 \mathrm{~cm}(\mathrm{se}=5.1)$, and elevation ranged from 1,375 to $1,472 \mathrm{~m}(\overline{\mathrm{x}}=1,429)$. Along an east/west line, the sites spanned $118 \mathrm{~km}$, and north/south extremes encompassed $75 \mathrm{~km}$. Climatological data reported herein were acquired at the Northern Great Basin Experimental Range (119 42' $30^{\prime \prime} \mathrm{W} 43^{\circ} 29^{\prime} 37^{\prime \prime} \mathrm{N}$ ) with the location identified as the Squaw Butte Experiment Station in N.O.A.A. records (N.O.A.A. 1991 through 1994).

The shrub layer at each site was dominated by Wyoming big sagebrush (Artemisia tridentata subsp. wyomingensis Beetle) with occasional occurrences ( $<10 \%$ relative cover) of mountain big sagebrush (Artemisia tridentata subsp. vaseyana (Rydb.) Beetle) at upper elevations. Dominant perennial grasses were typically bluebunch wheatgrass (Agropyron spicatum (Pursh) Scribn. \& Smith) or Idaho fescue (Festuca idahoensis Elmer). Subordinate grasses included Sandberg's bluegrass (Poa sandbergii Vasey), bottlebrush squirreltail (Sitanion hystrix (Nutt.) Smith), Thurber's needlegrass (Stipa thurberiana Piper), giant wildrye (Elymus cinereus Scribn. \& Merr.), prairie Junegrass (Koeleria cristata Pers.), and in disturbed areas, the introduced annual cheatgrass (Bromus tectorum L.). All of these grasses are common in the sagebrush steppe, and with the exception of prairie Junegrass, one or another may dominate the herbaceous layer depending on site specific conditions and environmental factors (Daubenmire 1970, Hironaka et al. 1983).

We evaluated 7 grasses in this study. Among these were Sandberg's bluegrass, a small stature, early maturing, caespitose, perennial grass and cheatgrass, an early maturing winter annual. The remaining 5 perennial grasses included bottlebrush squirreltail, bluebunch wheatgrass, Idaho fescue, Thurber's needlegrass, and giant wildrye. With the exception of giant wildrye, which can attain heights of up to $2 \mathrm{~m}$, these are mid-size caespitose grasses. In both years (1992 and 1993) we visited all 6 locations and sampled each within a 3day interval at the end of each month. Months sampled included April-November in both years.

Yearly precipitation compiled on a calendar year basis at the Northern Great Basin Experimental Range was 106 and $140 \%$ of the long-term average $(\bar{x}=283$ $\mathrm{mm}, \mathrm{n}=41$ ) for calendar years 1992 and 1993, respectively (N.O.A.A. 1992-1993). Sneva (1982), however, discovered that yearly forage yield in the region was most closely correlated with precipitation accumulated on a crop year or September through June basis. Based on that premise, accumulations for the 1992 and 1993 growing seasons at the Northern Great Basin Experimental Range were 86 and $167 \%$ of the crop year average $(255 \mathrm{~mm})$, respectively (Fig. 1). Both years of the study, however, experienced higher than average mid- to late-growing season rainfall. June-July precipitation totaled $68 \mathrm{~mm}$ in 1992 compared to an average of $34 \mathrm{~mm}$. In 1993 pooled July- August precipitation

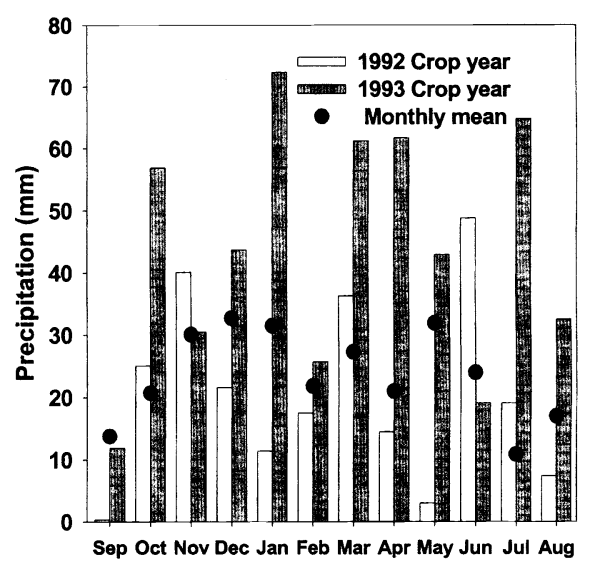

Fig. 1. Monthly precipitation for 1992 (Sept. 1991-June 1992) and 1993 (Sept. 1992-June 1993) crop-years, plus the months of July and August in 1992 and 1993, and mean monthly accumulations (n $=41$ ) for the Northern Great Basin Experimental Range near Burns, Ore. 
Table 1. P-values derived from a split-split-plot analyses of variance for mineral content of 7 grasses commonly found on northern Great Basin rangelands near Burns, Ore. Main effects were species of forage $(\mathrm{N}=7)$, years (1992 and 1993), and months (Apr.-Nov.). Shaded values are not statistically significant $(\mathbf{P}>0.05)$.

\begin{tabular}{|c|c|c|c|c|c|c|c|c|c|c|}
\hline \multirow[b]{2}{*}{ SOURCE } & \multirow[b]{2}{*}{ DF } & \multicolumn{9}{|c|}{ Mineral } \\
\hline & & $\mathrm{P}$ & $\mathrm{K}$ & $\mathrm{CA}$ & MG & $\mathrm{MN}$ & $\mathrm{FE}$ & $\mathrm{CU}$ & $\mathrm{ZN}$ & NA \\
\hline Species (S) & 6 & 0.001 & 0.001 & 0.001 & 0.001 & 0.001 & 0.001 & 0.001 & $0.008:$ & 0.019 \\
\hline Year $(\mathrm{Y})$ & 1 & 0.003 & 0.045 & 0.001 & 0.001 & 0.001 & 0.001 & 0.001 & 0.001 & 0.001 \\
\hline $\mathrm{Y} \times \mathrm{S}$ & 6 & 0.001 & 0.182 & 0.018 & 0.002 & 0.173 & 0.186 & 0.006 & 0.003 & 0.270 \\
\hline Month (M) & 7 & 0.001 & 0.001 & 0.001 & 0.001 & 0.004 & 0.001 & 0.001 & 0.001 & 0.001 \\
\hline $\mathrm{M} \times \mathrm{S}$ & 42 & 0.001 & 0.001 & 0.001 & 0.001 & 0.001 & 0.001 & 0.001 & 0.002 & 0.036 \\
\hline$Y \times M$ & 7 & 0.001 & 0.001 & 0.001 & 0.001 & 0.001 & 0.001 & 0.001 & 0.001 & 0.001 \\
\hline$Y \times M \times S$ & 42 & 0.009 & 0.001 & 0.001 & 0.001 & 0.010 & 0.002 & 0.046 & 0.261 & 0.388 \\
\hline
\end{tabular}

was $97 \mathrm{~mm}$ exceeding the long term mean of $27.2 \mathrm{~mm}$ by nearly $70 \mathrm{~mm}$. Mean April-July temperatures were $2.5^{\circ} \mathrm{C}$ warmer than average $\left(\overline{\mathrm{x}}=12.4^{\circ} \mathrm{C}\right)$ in 1992 and $1.6^{\circ}$ cooler than average in 1993. A model based on precipitation accumulations for predicting annual herbage yields in the region furnished production estimates of $542 \mathrm{~kg} \mathrm{ha}^{-1}$ for 1992 and $1,257 \mathrm{~kg} \mathrm{ha}^{-1}$ for 1993 (Sneva 1982). For the most part the grasses exerted few reproductive stems in 1992 and exhibited a wealth of reproductive effort in 1993.

At each site, samples were harvested from at least 6 plants per species by clipping to a $2.5-\mathrm{cm}$ stubble and compositing materials by species. Greater numbers of plants were used for small stature grasses like Sandberg's bluegrass. Plants at each site were sampled as they were encountered along a pace transect until adequate amounts of material were obtained. Each site experienced light ( $<40 \%$ utilization) summer/fall grazing by cattle, but only ungrazed plants were included in our collections. Samples harvested before spring growth consisted of leaves and culms produced in the previous growing season. After growth initiated in the spring, crowns of the caespitose grasses were lightly crushed and the brittle and broken old-growth brushed aside before samples were collected. Plant materials were stored in labeled, paper bags in the field and transported to Eastern Oregon Agricultural Research Center headquarters where they were oven-dried at $60^{\circ} \mathrm{C}$ for 48 hours, ground to pass a $1-\mathrm{mm}$ screen, and stored in plastic bags at room temperature for subsequent chemical assays. Samples were analyzed for calcium (Ca), phosphorus $(\mathrm{P})$, magnesium $(\mathrm{Mg})$, potassium $(\mathrm{K})$, copper $(\mathrm{Cu})$, zinc $(\mathrm{Zn})$, manganese $(\mathrm{Mn})$, sodium ( $\mathrm{Na}$ ), and iron ( $\mathrm{Fe})$. Assays were performed by The Research Extension Analytical Laboratory at The Ohio State University using Inductive Coupled Plasma (ICP) spectroscopy (Vela et al. 1993, Sirois et al. 1994). The specific instrument was an Applied Research Laboratory ICP Model $137^{1}$. Plant samples were dry-ashed, treated with $\mathrm{HNO}_{3}$, dissolved in HCL, and aspirated via an argon carrier into the ICP plasma chamber where ionized elements were quantified by emission spectroscopy (AOAC 1990).

To establish a reference point for the various minerals, the required levels in forages for beef cattle were extracted from NRC (1996) requirements. The reference animal was a 5-yr old $454 \mathrm{~kg}$ Hereford x Angus cross cow, trailing its third 120-day old calf, 60 days post breeding, with a body condition score of 5 , and consuming $2.5 \%$ (11.4 kg dry matter basis) of body weight per day.

Experimental design was a randomized complete block with 6 replications (sites) and 3 factors (years $(\mathrm{n}=2)$, months $(\mathrm{n}=$ 8 ), and species of forage $(n=7)$ ). Initial analyses employed a split-split-plot analysis of variance with species as wholeplots, years as subplots, and months as sub-subplots (Petersen 1985). The replication $\mathrm{x}$ species error term $(30 \mathrm{df})$ tested for species effects. The replication $\mathrm{x}$ year $\mathrm{x}$ species error term ( $35 \mathrm{df}$ ) tested the main effect of years and year $x$ species interaction. The species $\mathrm{x}$ year $\mathrm{x}$ replication $\mathrm{x}$ month error term (490 df) tested for main effects of months, species $\mathrm{x}$ month, and

${ }^{1}$ Tradenames are supplied for information only and do not constitute endorsement by USDA-ARS of any product to the exclusion of others that may be suitable. species $\mathrm{x}$ year $\mathrm{x}$ month interactions. Because all year main effects and 21 of 27 interactions involving year effects (Table 1) were significant $P<0.05)$, data were sorted by year, and each year analyzed separately employing a split-plot analysis of variance with species serving as whole plots and months as subplots. Mean separations between adjacent months within a species and year were obtained with Fisher's protected LSD procedures (Fisher 1966) with statistical significance accepted at $\mathrm{P} \leq$ 0.05 . All " \pm " symbols within this manuscript are associated with standard errors derived from 6 observations.

\section{Results and Discussion}

\section{Statistical analyses}

With our initial split-split-plot analyses of variance, the 3-way year $\mathrm{x}$ month $\mathrm{x}$ species interaction was significant $(\mathrm{P}<$ 0.05 ) for 7 of 9 elements (exceptions were $\mathrm{Zn}$ and $\mathrm{Na}$ (Table 1)). That being the case, the 3 main effects did not function independently, and a majority of the data must be presented in a 3-way format. To briefly communicate the relative amounts of variation associated with our initial split-splitplot analyses, component variances were totaled across all 9 elements. Year, month, and species main effects respectively accounted for 42,29 , and $9 \%$ of the total variation (data not shown). Among the 2way interactions year $\mathrm{x}$ species constituted $2.1 \%$ month $\mathrm{x}$ species $1.8 \%$, and year $\mathrm{x}$ month $9.6 \%$. The 3 -way year $x$ month $x$ species interaction contributed $0.6 \%$. Among error terms, number 1 (rep x species) contributed $1.0 \%$, number 2 (species (rep x year)) contributed $0.7 \%$, and error term 3 approximately $0.4 \%$. 
Table 2. P-values derived from separate split-plot analyses of variance for 1992 and 1993 mineral content of 7 grasses found on northern Great Basin rangelands near Burns, Ore. Main effects are species of forage $(\mathrm{N}=7)$ and months (Apr.-Nov.). Shaded values are not statistically significant $(P>$ 0.05).

\begin{tabular}{|c|c|c|c|c|c|c|c|c|c|c|}
\hline \multicolumn{11}{|c|}{1992} \\
\hline \multicolumn{11}{|c|}{ Minerals } \\
\hline SOURCE & $\mathrm{DF}$ & $\mathrm{P}$ & $\mathrm{K}$ & $\mathrm{CA}$ & MG & $\mathrm{MN}$ & $\mathrm{FE}$ & $\mathrm{CU}$ & $\mathrm{ZN}$ & NA \\
\hline Species (S) & 6 & 0.004 & 0.001 & 0.001 & 0.001 & 0.001 & 0.001 & 0.001 & 0.329 & 0.014 \\
\hline Month (M) & 7 & 0.001 & 0.001 & 0.001 & 0.001 & 0.001 & 0.001 & 0.001 & 0.001 & 0.001 \\
\hline$M \times S$ & 42 & 0.001 & 0.001 & 0.001 & 0.001 & 0.001 & 0.001 & 0.001 & 0.232 & 0.139 \\
\hline \multicolumn{11}{|c|}{1993} \\
\hline \multicolumn{11}{|c|}{ Minerals } \\
\hline SOURCE & $\mathrm{DF}$ & $\mathrm{P}$ & $\mathrm{K}$ & $\mathrm{CA}$ & MG & $\mathrm{MN}$ & $\mathrm{FE}$ & $\mathrm{CU}$ & $\mathrm{ZN}$ & NA \\
\hline Species (S) & 6 & 0.001 & 0.001 & 0.001 & 0.001 & 0.001 & 0.002 & 0.001 & 0.001 & 0.012 \\
\hline Month (M) & 7 & 0.001 & 0.001 & 0.001 & 0.001 & 0.002 & 0.001 & 0.001 & 0.001 & 0.001 \\
\hline $\mathrm{M} \times \mathrm{S}$ & 42 & 0.001 & 0.001 & 0.001 & 0.001 & 0.001 & 0.003 & 0.001 & 0.001 & 0.207 \\
\hline
\end{tabular}

Replications or sites accounted for $3.7 \%$ of the total variation.

When year effects were removed from the model and each year analyzed separately, 15 of 18 month $x$ species interactions (Table 2) were significant $(\mathrm{P} \leq 0.01)$. That being the case, species did not react similarly as we progressed from month to month within years and again data must be presented for each species at monthly intervals for the majority of the data. Two of the 3 month $x$ species exceptions involved $\mathrm{Na}$ $(P>0.13)$ in both 1992 and 1993. Main effects of species and month were significant $(\mathrm{P} \leq 0.02)$, however, suggesting that while Na concentrations differed among the grasses, they responded similarly as we progressed from month to month. The third exception to a significant $(P=0.23)$ month $\mathrm{x}$ species interaction was $\mathrm{Zn}$ in 1992 . Species effects were not significant $(\mathrm{P}=$ 0.32 ) either in that analysis suggesting that monthly means compiled across species would adequately describe $\mathrm{Zn}$ dynamics of the grasses in 1992. Both main effects and the month $x$ species interaction were significant $(\mathrm{P}<0.01)$ for $\mathrm{Zn}$ in 1993, however. When components of these analyses of variance were totaled across years and minerals, month effects accounted for $46 \%$ of the total variation, species of grass about $31 \%$, replications or locations about $12.5 \%$, the species $\mathrm{x}$ month interaction $4.9 \%$, error term number 1 about $3.8 \%$, and error term two, $1.9 \%$. Again, given the preponderance of significant 2 and 3-way interactions in our analyses, data will be presented at monthly resolutions for each year for each species of grass.

\section{Calcium}

Among grasses and for the duration of the study, mean $\mathrm{Ca}$ concentration was 2.99 $\mathrm{g} \mathrm{kg}^{-1}( \pm 0.08)$. Given that all interactions were significant $(\mathrm{P}<0.05)$ among all analyses, there was great variability among forages and months and between years (Fig. 2). With the exception of the winter annual, cheatgrass, most of the grasses began the growing season with a Ca content just at or below $3.2 \mathrm{~g} \mathrm{~kg}^{-1}$, the concentration necessary to meet NRC (1996) requirements for beef cattle. Sandberg's bluegrass, however, never exceeded the recommended $\mathrm{Ca}$ level for cattle in any month of either year. Sandberg's bluegrass responded to November precipitation in 1992 with elevated $(\mathrm{P}<0.05) \mathrm{Ca}$ levels that approached the required level, and cheatgrass responded with significant increases $(\mathrm{P}<0.05)$ to November rains in both years. Among the medium and large stature perennial grasses (bottlebrush squirreltail, bluebunch wheatgrass, Idaho fescue, Thurber's needlegrass and giant wildrye), however, Ca content typically peaked well above recommended levels in late-July and then declined as these grasses matured and entered quiescence. None of these 5 grasses, however, exhibited significant increases in Ca levels with the arrival of fall (October/November) moisture.

A general pattern evident among all the grasses was that $\mathrm{Ca}$ levels were typically higher $(\mathrm{P}<0.05)$ during the dry 1992 growing season than the more moist 1993 months. The dilution of mineral concentrations with more favorable growing con- ditions is frequently seen and attributed to accumulation of more carbon under optimal conditions. Conversely, growth restriction during drought is accompanied by mineral concentration. With minimal selective grazing among these forages, cattle could have easily ingested sufficient $\mathrm{Ca}$ during the full 8-month sampling period of 1992. By selecting for cheatgrass early in the growing season and bluebunch wheatgrass later in the year, cattle could have potentially acquired sufficient $\mathrm{Ca}$ for 7 of the 8 months sampled in 1993. All of the grasses, however, were $\mathrm{Ca}$ deficient for cattle during the late June-July interval of 1993. Typically though, unless cattle are heavily lactating or foraging on rapidly growing herbage on acid, sandy, or organic soils, clinical signs of $\mathrm{Ca}$ deficiencies are rare among grazing beef cattle (Underwood 1981).

\section{Magnesium}

Pooled across years, months, and forages mean $\mathrm{Mg}$ content was $0.94 \mathrm{~g} \mathrm{~kg}^{-1}( \pm$ 0.006 ), and the concentration necessary to meet NRC (1996) requirements was $1.15 \mathrm{~g}$ $\mathrm{kg}^{-1}$. Like $\mathrm{Ca}$, all interactions were significant $(\mathrm{P}<0.01)$ among all 3 analyses of variance (Tables 1 and 2 ) again indicative that annual and seasonal $\mathrm{Mg}$ contents of the grasses were quite variable among year, month, and species combinations

Cheatgrass exceeded the required level of $\mathrm{Mg}$ from early May to late June of both years (Fig. 3). Idaho fescue also equaled or exceeded the $\mathrm{Mg}$ requirements of cattle in the early growing season, and both bottlebrush squirreltail and giant wildrye fur- 

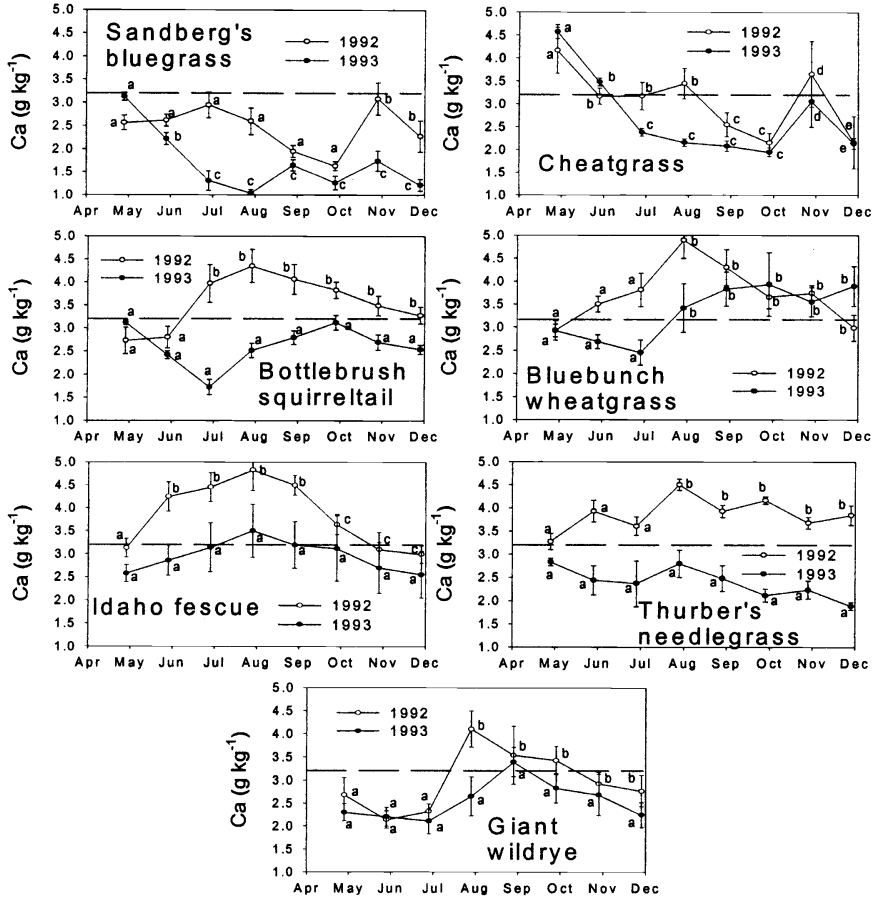

Fig. 2. Mean calcium content $( \pm \mathrm{SE}$ bars) of 7 grasses sampled over 8 months at 6 sites in the sagebrush steppe near Burns, Ore. in 1992 and 1993. The dashed horizontal line denotes required Ca content of forages for a $454 \mathrm{~kg}$ cow. Adjacent monthly means within a year sharing a common letter are not significantly $(P>0.05)$ different. Fisher's protected LSD $(P=0.05)=0.85$ and $0.84 \mathrm{~g} \mathrm{~kg}^{-1}$, respectively, for 1992 and 1993.
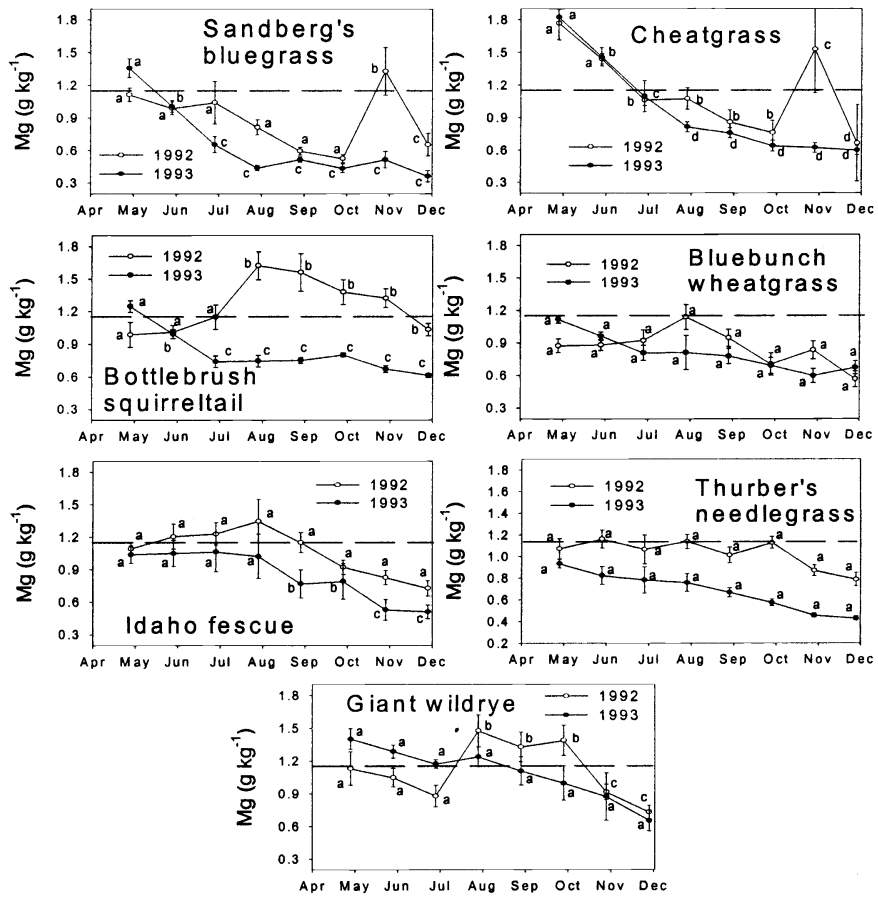

Fig. 3. Mean magnesium content $( \pm \mathrm{SE}$ bars $)$ of 7 grasses sampled over 8 months at 6 sites in the sagebrush steppe near Burns, Ore. in 1992 and 1993. The dashed horizontal line denotes required Mg content forages for a $454 \mathrm{~kg}$ cow. Adjacent monthly means within a year sharing a common letter are not significantly $(P>$ $0.05)$ different. Fisher's protected LSD $(P=0.05)=0.34$ and 0.24 $\mathrm{g} \mathrm{kg}^{-1}$, respectively, for 1992 and 1993. nished adequate levels of Mg from July into November of 1992. Both Sandberg's bluegrass and cheatgrass responded to October rains with significant increases in $\mathrm{Mg}$ that exceeded requirements of cattle in 1992. Magnesium content of bluebunch wheatgrass marginally approached the required level for cattle for only 1-sampling period each year. Both bluebunch wheatgrass and Thurber's needlegrass were notable because neither species exhibited a significant $(P>0.05)$ month to month change in $\mathrm{Mg}$ content for either year. When pooled across species within years, selective grazing by cattle could have furnished adequate $\mathrm{Mg}$ level for all but the last 15 days of November in 1992 . In 1993, however, none of the grasses provided adequate $\mathrm{Mg}$ from mid-August through late-November. Grass tetany generally occurs during early spring, when grasses are exhibiting rapid vegetative growth (McDowell and Valle 2000), and lactation demands of cattle are peaking. With the exception of cheatgrass, which was found primarily on disturbed sites, and giant wildrye early in the 1993 growing season, our grasses were marginally satisfactory or deficient for $\mathrm{Mg}$ from late-
April into late June. Bottlebrush squirreltail, Idaho fescue, and giant wildrye furnished adequate $\mathrm{Mg}$ for the July-October period in 1992, but nearly all of the grasses were deficient beyond late-June for the 1993 growing season.

\section{Phosphorus}

Mean $\mathrm{P}$ concentration among grasses over the trials was $1.42 \mathrm{~g} \mathrm{~kg}^{-1}( \pm 0.09)$, and the concentration necessary to meet NRC (1996) requirements was $1.94 \mathrm{~g} \mathrm{~kg}^{-1}$. Maximum and minimum values detected were 5.04 and $0.28 \mathrm{~g} \mathrm{~kg}^{-1}$, respectively. While all interactions were again significant $(\mathrm{P}<0.01)$ among all 3 analyses of variance (Tables 1 and 2 ), $P$ did not exhibit the same degree of year to year variability among species and months (Fig. 4) as $\mathrm{Ca}$ and $\mathrm{Mg}$. The general pattern among the grasses was that $\mathrm{P}$ levels equaled or exceeded cattle requirements early in the growing season and rapidly declined to inadequate levels by late July or early August in both years. Phosphorus levels were consistently higher $(\mathrm{P}<0.05)$ for the early portions of the 1993 growing season than for the early months of 1992. In
1992, cheatgrass sustained adequate levels of phosphorus until mid-July, while all of the remaining grasses were largely deficient by mid-June. Sandberg's bluegrass and cheatgrass responded to October 1992 precipitation with significant $(\mathrm{P}<0.05)$ increases in $\mathrm{P}$ during November, but adequate $\mathbf{P}$ levels for cattle were not sustained into December. The other medium stature grasses showed no significant $(\mathrm{P}>0.05)$ responses to fall moisture in either year.

On a worldwide basis, the most prevalent mineral deficiency among livestock is probably phosphorus (Underwood 1981). Phosphorus deficiencies are more prominent among tropical grasses than temperate forages (McDowell et al. 1984), and the most devastating result of deficiency among cattle is reproductive failure (McDowell and Valle 2000). Where serious deficiencies occur, lactating cows may not enter oestrus until they cease milking or are supplemented with phosphorus (Lammond, 1970). Olson (1971) noted increased gains by cattle on southern Idaho cheatgrass ranges when phosphorus was supplemented. 

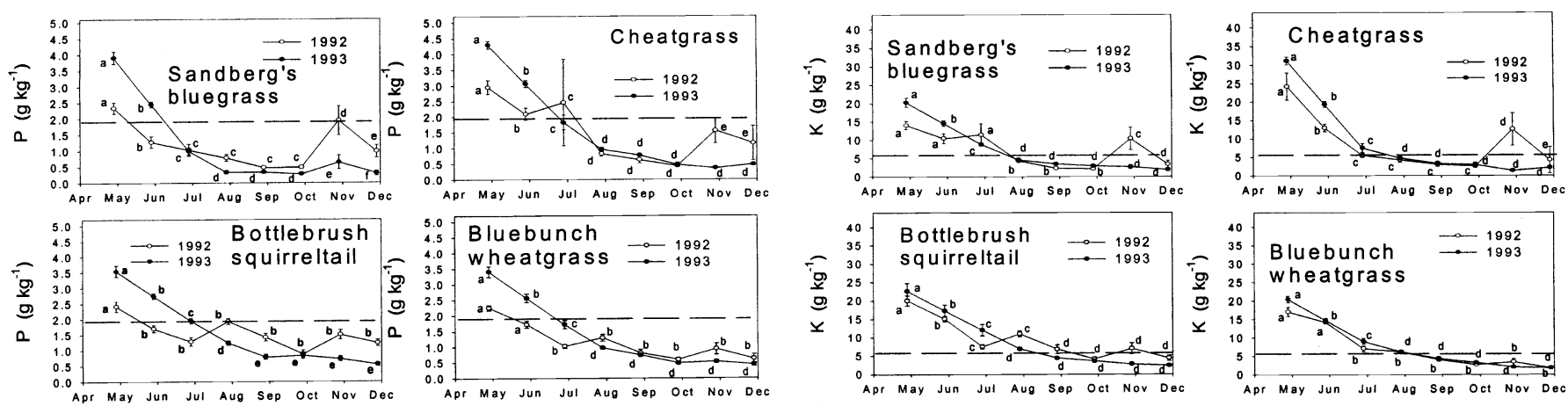

5.0 Bluebunch

4.5. Bluebunch $\longrightarrow 1992$

3.5. Whe a
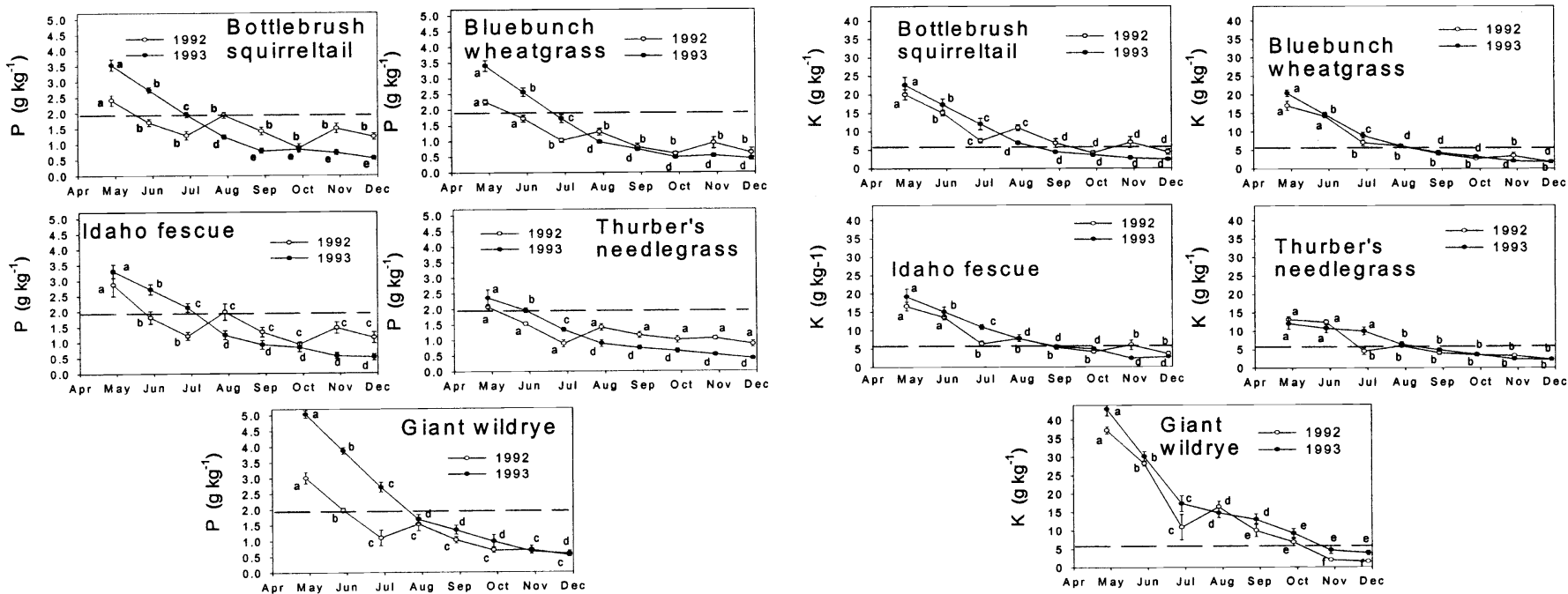

Fig. 4. Mean phosphorus content $( \pm \mathrm{SE}$ bars) of 7 grasses sampled over 8 months at 6 sites in the sagebrush steppe near Burns, Ore. in 1992 and 1993. The dashed horizontal line denotes required $P$ content of forages for a $454 \mathrm{~kg}$ cow. Adjacent monthly means within a year sharing a common letter are not significantly $(P>$ 0.05) different. Fisher's protected LSD $(P=0.05)=0.66$ and $0.34 \mathrm{~g}$ $\mathrm{kg}^{-1}$, respectively, for 1992 and 1993.

\section{Potassium}

Mean $\mathrm{K}$ content of all forages was $9.0 \mathrm{~g}$ $\mathrm{kg}^{-1}( \pm 0.74)$, and seasonal values ranged from a high of 42.9 to a low of $1.39 \mathrm{~g} \mathrm{~kg}^{-1}$ (Fig. 5). The concentration in forages needed to meet NRC (1996) requirements for beef cattle was $5.76 \mathrm{~g} \mathrm{~kg}^{-1}$. Again the significant 3-way year $\mathrm{x}$ month $\mathrm{x}$ species interaction implied that $\mathrm{K}$ concentrations did not respond similarly between years and that species were not similar across months. In both years, all of the grasses began the growing season with adequate $\mathrm{K}$ levels for beef cattle. Sandberg's bluegrass and cheatgrass were the first forages to exhibit inadequate $\mathrm{K}$ concentrations for cattle becoming deficient by approximately late-July in both years. Bluebunch wheatgrass, bottlebrush squirreltail, Idaho fescue, and Thurber's needlegrass, however, sustained adequate levels of $\mathrm{K}$ into mid-August or early September. Giant wildrye was notable because it sustained adequate amounts of $\mathrm{K}$ until about midOctober of both years. Both Sandberg's bluegrass and cheatgrass responded to October 1992 precipitation with increased levels $(\mathrm{P}<0.05)$ of $\mathrm{K}$. None of the other forages displayed a response to fall precip- itation, and all of the grasses were $\mathrm{K}$ deficient by about mid- November.

McDowell and Valle (2000) found few reports of a $\mathrm{K}$ deficiency among ruminants foraging under natural conditions. Potassium typically exists as a cellular constituent among animals, but it occurs at much higher levels in milk than sodium. That being the case, lactating cattle can not conserve supplies as effectively as their nonlactating counterparts (Maynard and Loosli 1969). When deficiencies do occur, general symptoms include: slow growth, reduced feed and water intake, lowered feed efficiency, weakness, nervous disorders, and degeneration of vital organs. Potassium deficiencies are usually not seen, however, because associated nutrients are typically even more deficient and their symptoms manifested much sooner than those of potassium (McDowell and Valle 2000).

\section{Copper}

Copper concentration of the 7 grasses averaged $1.75 \mathrm{mg} \mathrm{kg}^{-1}( \pm 0.11)$. While all interactions were significant for each analysis of variance ( $P \leq 0.46)$, the seasonal dynamics of these grasses are of lit- tle interest, because their $\mathrm{Cu}$ content never approached the NRC (1996) requirement for cattle forages of $9.6 \mathrm{mg} \mathrm{kg}^{-1}$ (Fig. 6). Cheatgrass and giant wildrye consistently began the growing seasons with higher levels of $\mathrm{Cu}$ than the other grasses, but all of the grasses provided only 10 to $25 \%$ of the $\mathrm{Cu}$ required for cattle by about July or August. Idaho fescue was notable in that no significant $(\mathrm{P}>0.05)$ month to month changes in $\mathrm{Cu}$ content occurred in 1992 or 1993. Seasonal dynamics were not substantial either for bottlebrush squirreltail, bluebunch wheatgrass or Thurber's needlegrass.

Availability of dietary copper to animals is affected by interactions with Mo, S, and Fe (Suttle 1981), with excesses of either retarding copper availability. A wide array of symptoms accompany copper deficiencies among cattle, and their diversity may be linked to complex interactions involving other minerals. Some of the clinical signs include: bleaching of hair, nervous symptoms (ataxia) in calves whose dams experienced deficiency during pregnancy, lameness, and swelling of joints (Maynard and Loosli 1969). Serum assays of beef cattle by Raleigh (1988) in south-east 

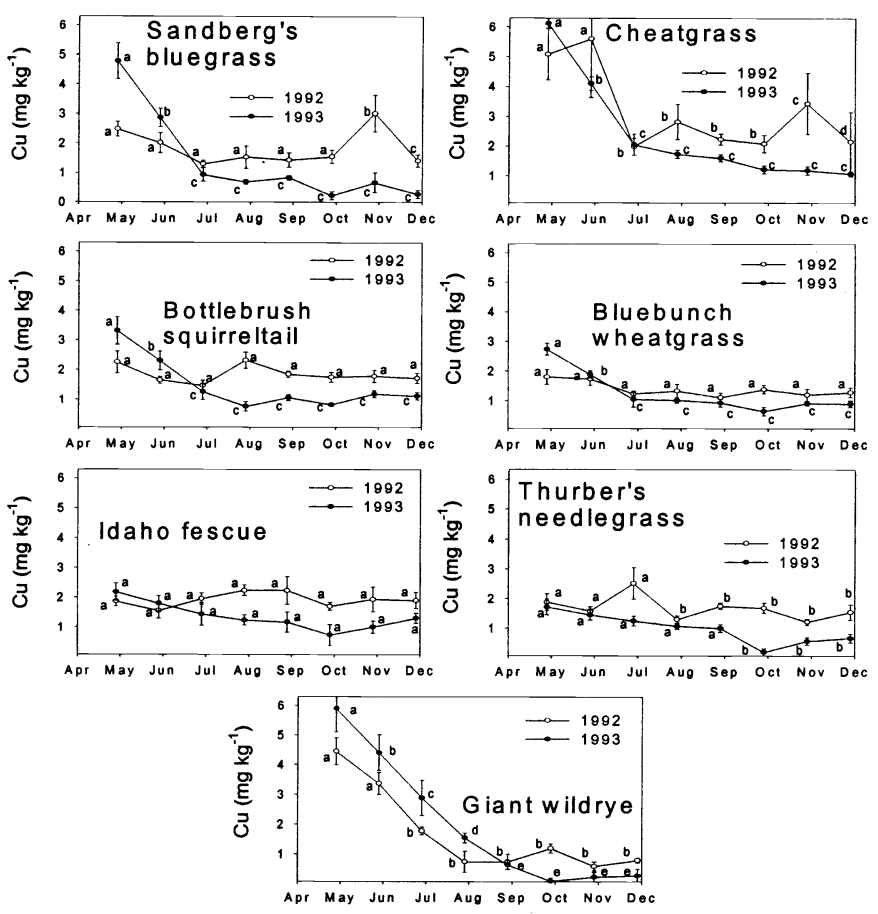

Fig. 6. Mean copper content $(\underset{+}{\mathrm{SE}}$ bars) of 7 grasses sampled over 8 months at 6 sites in the sagebrush steppe near Burns, Ore. in 1992 and 1993. The required copper content of forages for a 454 $\mathrm{kg}$ cow is $9.6 \mathrm{mg} \mathrm{kg}^{-1}$. Adjacent monthly means within a year sharing a common letter are not significantly $(P>0.05)$ different. Fisher's protected LSD $(P=0.05)=1.19$ and $0.73 \mathrm{mg} \mathrm{kg}^{-1}$, respectively, for 1992 and 1993.
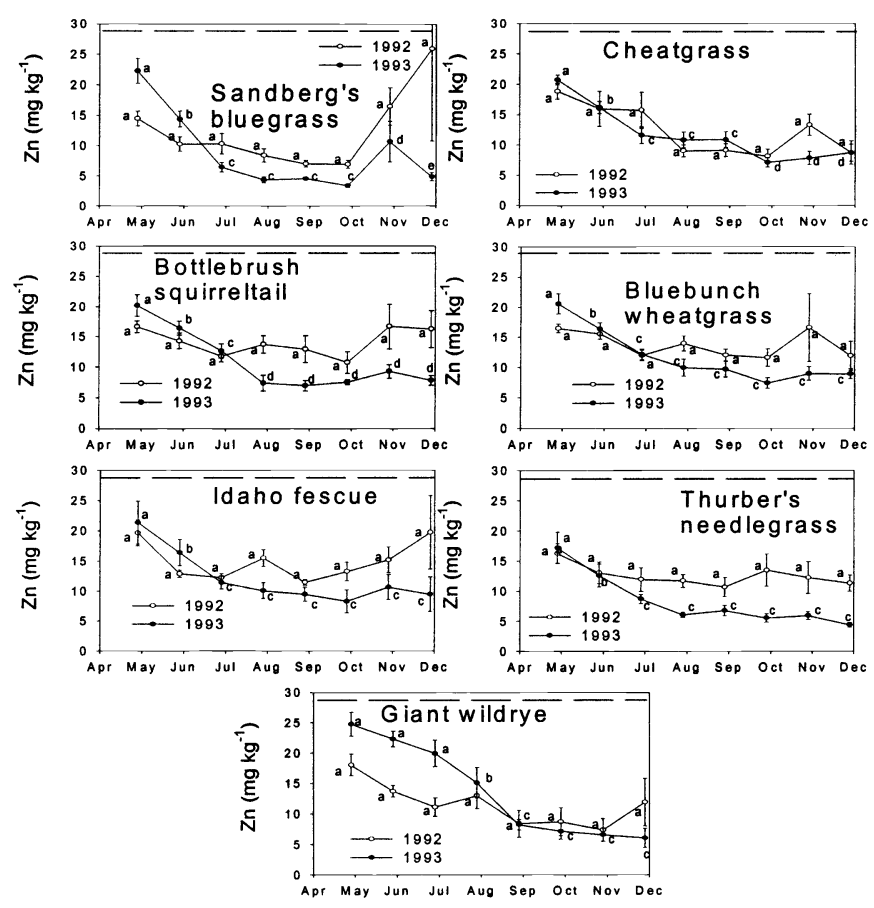

Fig. 7. Mean zinc content $( \pm \mathrm{SE}$ bars) of 7 grasses sampled over 8 months at 6 sites in the sagebrush steppe near Burns, Ore. in 1992 and 1993. The required zinc content of forages for a $454 \mathrm{~kg}$ cow is $28.8 \mathrm{mg} \mathrm{kg}^{-1}$ (dashed horizontal line). Adjacent monthly means within a year sharing a common letter are not significantly different $(P>0.05)$. Fisher's protected LSD $(P=0.05)=7.82$ and 3.75 $\mathrm{mg} \mathrm{kg}^{-1}$, respectively, for 1992 and 1993.
Oregon revealed marginal $\mathrm{Cu}$ levels, and up until 1988 clinical symptoms had not been noted. Recently, however, some herds in southeast Oregon have developed health and reproductive disorders attributed to $\mathrm{Cu}$ deficiency. Consequently, many producers have begun monitoring the $\mathrm{Cu}$ status of their animals and become more attentive to management of their mineral programs.

\section{Zinc}

Mean $\mathrm{Zn}$ content of the grasses was 12.1 $\mathrm{mg} \mathrm{kg}^{-1}( \pm 0.44)$. With our full ANOVA model, species effects $(P=0.09)$ and the 3 -way interaction $(P=0.26)$ were not significant (Table 1). When years were analyzed separately, however, all 7 grasses responded similarly as we advanced from month to month in 1992 , but both main effects (Table 2) and the month $x$ species interaction were significant $(\mathrm{P}<0.01)$ for 1993. In 1993, all 7 grasses exhibited a nearly linear or curvilinear decline of $\mathrm{Zn}$ as the seasons progressed (Fig. 7). Sandberg's bluegrass was the only forage to show a significant $(P<0.05)$ increase of $\mathrm{Zn}$ with the advent of fall precipitation in 1993. Despite these dynamics, none of the grasses sampled met the NRC (1996) required concentration of $\mathrm{Zn}$ for beef cattle forage $\left(28.8 \mathrm{mg} \mathrm{kg}^{-1}\right)$ for any sampling period in either year. Fleming (1963) noted that zinc content varies considerably among components of grass plants and found leaf/stem/flower concentrations of 20,15 , and $36 \mathrm{mg} \mathrm{kg}^{-1}$, respectively. Zinc deficiencies can cause parakeratosis (inflamed skin around nose and mouth), stiffness of joints, alopecia, breaks in skin around the hoof, and retarded growth. Deficiencies have been induced experimentally in calves (Miller and Miller 1960), and while no applied reports of $\mathrm{Zn}$ deficiencies have occurred in sheep or cattle (Maynard and Loosli 1969), Mayland et al. (1980) saw improved gains among calves supplemented with zinc in southern Idaho.

\section{Manganese}

Manganese concentrations varied significantly $(\mathrm{P}<0.01)$ between years, and forages did not exhibit similar patterns as we advanced from month to month (Table 1) in either year. Variability among samples within months was high, however, and significant $(\mathrm{P}<0.05)$ month to month changes in Mn concentration were difficult to establish within each species, especially in 1993 (Fig. 8).

With the exception of the beginning of the growing season (late-April), monthly Mn levels were generally higher for 1992 than for 1993. The NRC (1996) requirement for beef cattle was $38 \mathrm{mg} \mathrm{kg}^{-1}$, and mean Mn content of forages over the 2 sampling seasons was $38.6 \mathrm{mg} \mathrm{kg}^{-1}$ ( \pm $1.3)$. Only cheatgrass contained adequate concentrations of $\mathrm{Mn}$ early in the growing season, and it exceeded beef cattle requirements for all but the last months of both years. Other grasses, however, like bluebunch wheatgrass or bottlebrush squirreltail, consistently supported adequate levels of Mn late in the year, so cattle consuming a diverse diet could probably ingest sufficient $\mathrm{Mn}$ on a season long basis. Except for giant wildrye, which only contained adequate $\mathrm{Mn}$ levels in early May of both years, the other perennial bunchgrasses displayed more than required Mn levels from early to mid-June through early December in 1992. Sandberg's bluegrass, bluebunch wheatgrass, Idaho fescue, and Thurber's needlegrass were largely Mn deficient for beef 

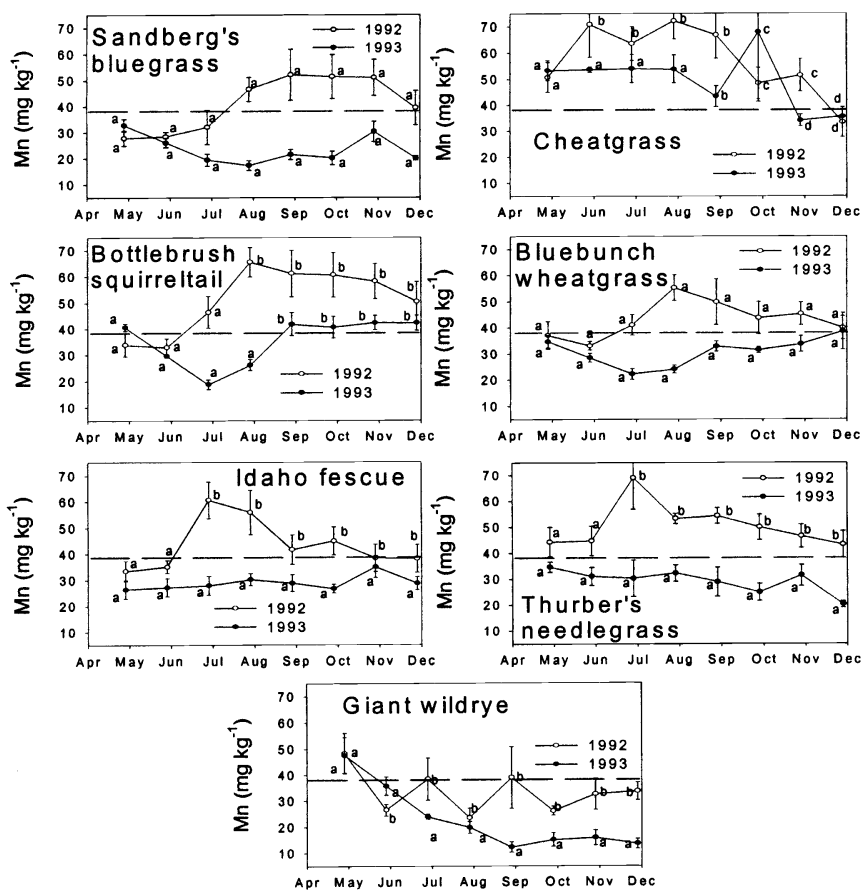

Fig. 8. Mean manganese content $( \pm \mathrm{SE}$ bars $)$ of 7 grasses sampled over 8 months at 6 sites in the sagebrush steppe near Burns, Ore. in 1992 and 1993. The dashed horizontal line denotes the required Mn content of forages for a $454 \mathrm{~kg}$ cow. Adjacent monthly means within a year sharing a common letter are not significantly $(P>$ 0.05) different. Fisher's protected LSD $(P=0.05)=16.5$ and 13.3 $\mathrm{mg} \mathrm{kg}^{-1}$, respectively, for 1992 and 1993.
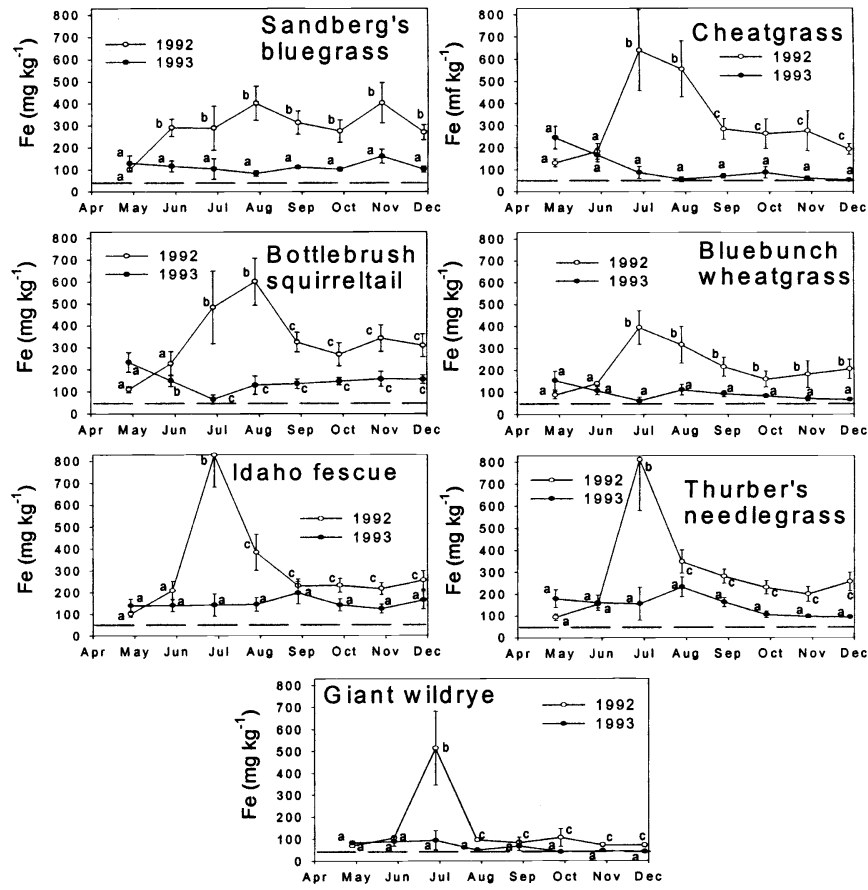

Fig. 9. Mean iron content $( \pm \mathrm{SE}$ bars) of 7 grasses sampled over 8 months at 6 sites in the sagebrush steppe near Burns, Ore. in 1992 and 1993. The dashed horizontal line denotes required $\mathrm{Fe}$ content of forages for a $454 \mathrm{~kg}$ cow. Adjacent monthly means within a year sharing a common letter are not significantly $(P>0.05)$ different. Fisher's protected LSD $(P=0.05)=191.7$ and $79.8 \mathrm{mg} \mathrm{kg}^{-1}$, respectively, for 1992 and 1993. cattle in the 1993 growing season and fall months. Giant wildrye cycled between being adequate and marginally deficient in 1992 and was largely deficient for the bulk of the 1993 sampling period.

\section{Iron}

With the exception of the year $\mathrm{x}$ species interaction $(P=0.186)$ in our initial analyses, (Table 1) most components of our analyses for Fe were significant $(\mathrm{P}<0.01)$ (Table 2). Over the trial, mean Fe content of the grasses was $194.4 \mathrm{mg} \mathrm{kg}^{-1}$, and each of the grasses exceeded or equaled beef cattle forage requirements of $48 \mathrm{mg} \mathrm{kg}^{-1}$ for all months sampled (Fig. 9). With the exception of the beginning of the growing season, Fe content of the grasses was higher $(\mathrm{P}<0.01)$ in 1992 than in 1993 . The 1992 sampling period also exhibited more seasonal dynamics within each grass than 1993 (Fig. 9), and we have some suspicion that rainfall and associated soil contamination of samples may have elevated Fe concentrations of our July 1992 period (Mayland and Sneva 1983). In 1993, the only significant $(\mathrm{P}<0.05)$ month to month change in $\mathrm{Fe}$ concentration involved decreasing levels in bottlebrush squirreltail between late-April and late-June. It appears that above average June rainfall in 1992 stimulated Fe uptake $(\mathrm{P}<0.05)$ by all of the grasses except Sandberg's bluegrass, while above average precipitation in July 1993 had no significant $(P>0.05)$ effect on Fe uptake.

\section{Sodium}

Sodium concentrations varied considerably among the grasses with substantial monthly differences between years $(\mathrm{P}<$ 0.01) (Table 1). While species and monthly differences $(\mathrm{P}<0.05)$ occurred within years, all the grasses responded similarly $(\mathrm{P}>0.13)$ as we advanced from month to month (Table 2 and Fig. 10) within each year. With the exception of the beginning of the growing season, monthly concentrations were typically higher for all the grasses in 1992 than in 1993. The NRC recommended sodium content for beef cattle forages was $672 \mathrm{mg} \mathrm{kg}^{-1}$, and all of our forages were deficient throughout both years. Mean $\mathrm{Na}$ content of forages for the study was only $61.3 \mathrm{mg} \mathrm{kg}^{-1}$. The highest $\mathrm{Na}$ content attained by any of the grasses was Sandberg's bluegrass in late-October of 1992, and even then, it averaged only $177 \mathrm{mg} \mathrm{kg}^{-1}$ (Fig. 10).
Among animals, $\mathrm{Na}$ is found primarily in extracellular fluids. In conjunction with $\mathrm{K}$ and $\mathrm{Cl}$, it assists with maintaining osmotic pressure, acid-base equilibrium, nutrient passage into cells, and water metabolism in general (Maynard and Loosli 1969). Animals have considerable ability to conserve $\mathrm{Na}$, but again that luxury is not available to lactating individuals (McDowell and Valle 2000) suffering from a lack of salt in the diet. Prolonged deficiencies cause loss of appetite, decreased growth or weight loss, unthrifty appearance and reduced milking (McDowell and Valle 2000), but supplemental salt can also stimulate weight gains (McDowell et al. 1984) among animals that are not showing signs of deficiencies.

\section{Management implications}

Cattle in the sagebrush/steppe typically derive 85 to $90 \%$ of their annual rangeland diet from grasses (Vavra and Sneva 1978, McInnis and Vavra 1987). Seasonally, spring/summer forbs may contribute as much as $6-9 \%$ of the diet, and shrubs may account for $12-15 \%$ of intake during fall and winter (McInnis and Vavra 1987). Given the preponderance of grasses in cattle diets, however, many of the patterns 

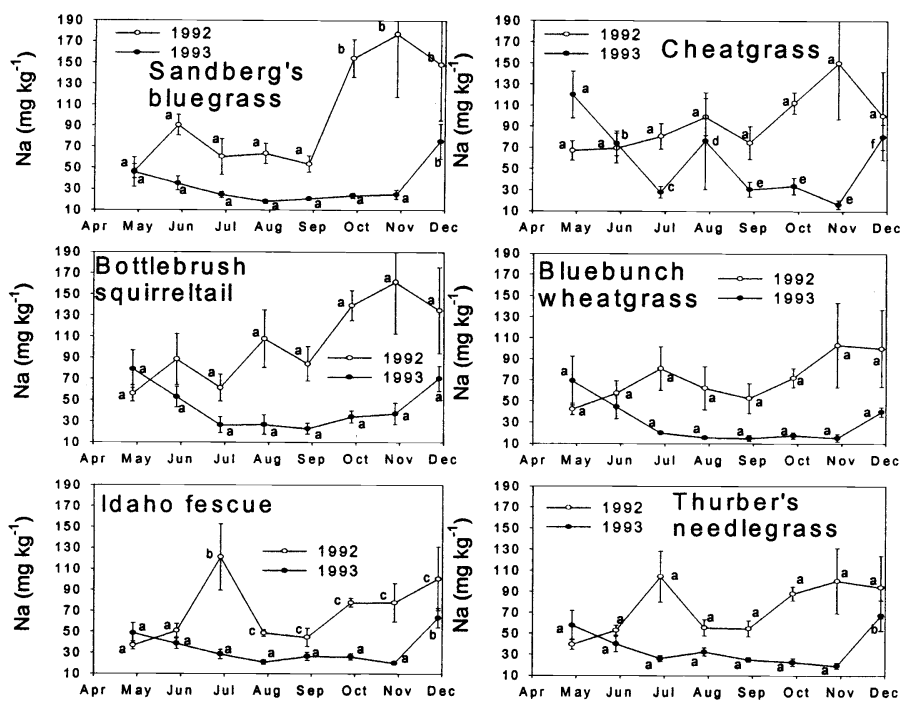

170 Bluebunch $\longrightarrow 1992$

150
130
110

130
110
90

$\left.\begin{array}{l}90 \\ 70 \\ 50 \\ 10\end{array}\right]$

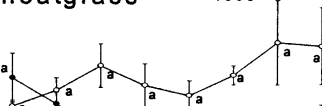

Apr May Jun Jul Aug sep Oct Nov Dec

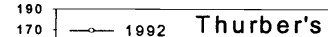

- 1993 needlegras

130
110
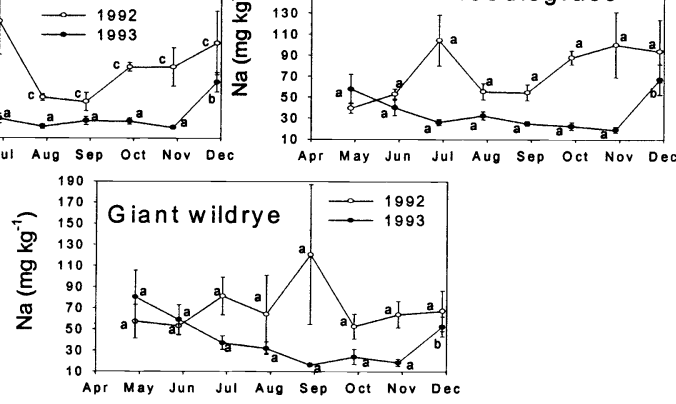

Fig. 10. Mean sodium content ( \pm SE bars) of 7 grasses sampled over 8 months at 6 sites in the sagebrush steppe near Burns, Ore. in 1992 and 1993. The required sodium content of forages for a $454 \mathrm{~kg}$ cow is $672 \mathrm{mg} \mathrm{kg}^{-1}$. Adjacent monthly means within a year sharing a common letter are not significantly $(P>0.05)$ different. Fisher's protected LSD $(P=0.05)$ $=61.5$ and $30.8 \mathrm{mg} \mathrm{kg}^{-1}$, respectively, for 1992 and 1993 .

and generalizations from this study are especially relevant to beef cattle management and animal performance.

Of major interest were those minerals that occurred at deficient levels among grasses on a year around basis. These included $\mathrm{Cu}, \mathrm{Zn}$, and $\mathrm{Na}$, and their deficiencies should most definitely be given some consideration by stockman (Figs. 6, 7, and 10). Seasonally deficient minerals included $\mathrm{Ca}, \mathrm{Mg}, \mathrm{P}, \mathrm{K}$, and $\mathrm{Mn}$. Among the caespitose grasses, $\mathrm{Ca}$ and $\mathrm{Mn}$ were largely deficient for cattle early in the growing season with levels increasing as the grasses advanced into summer (Figs. 2 and 8). Magnesium patterns were less generalized (Fig. 4) because some grasses displayed increasing concentrations as the seasons progressed (giant wildrye and bottlebrush squirreltail), some remained relatively stable through the seasons (bluebunch wheatgrass and Thurber's needlegrass), and others declined (Sandberg's bluegrass and cheatgrass). Phosphorus and $\mathrm{K}$ levels were typically adequate early in the growing season and declined to deficient levels by July and August, respectively (Figs. 4 and 5). Iron was of no concern, because levels were more than adequate among all the grasses for all periods sampled. However, high levels of Fe could potentially lower $\mathrm{Cu}$ availability and exasperate management problems associated with copper deficiencies.

Also of interest was the year to year dynamics that occurred among minerals within a species. With the exception of a few early and late season reversals, a gross generalization was that mineral concentrations were higher during the 1992 growing season than for 1993 . We did not quantify leaf/stem/flower ratios of our samples, but our field notes clearly indicated that very few grasses completed the reproductive phases of phenology during the 1992 growing season. Abundant early moisture in 1993, however, allowed great numbers of tillers to fully complete their reproductive efforts before going dormant. That being the case, the summer/fall 1992 samples were largely vegetative in nature, while the 1993 samples contained a wealth of reproductive stems. These reproductive stems do add biomass, as 1993 standing crop was more than twice that of 1992 (Ganskopp and Bohnert 2001), but they dilute nutritive value (Ganskopp et al. 1992, Mayland and Shewmaker 1997), because they are largely generated for structural support of reproductive parts.

Angell et al. (1990) noted significant disparities in crude protein content of crested wheatgrass at equivalent dates and stages of morphological development among years, and our data also exhibit some substantial disparities within months and between years for each species. Calcium, $\mathrm{Mg}$, and $\mathrm{Mn}$ concentrations fluctuated greatly between years, and indeed some grasses supported deficient levels for 1 sampling season and more than adequate levels for beef cattle during a second. The clearest and most radical example was Thurber's needlegrass with $\mathrm{Ca}$ and $\mathrm{Mn}$ between 1992 and 1993 (Figs. 2 and 8). Both minerals were more than adequate in 1992 and at deficient concentrations for all of the 1993 sampling period. Other grasses like bottlebrush squirreltail, bluebunch wheatgrass, and Idaho fescue approached this same pattern, but there were periods in both years when they contained deficient concentrations.

Indeed plant mineral dynamics and animal mineral nutrition are complex issues, and our most prominent forages are clearly deficient for one or more minerals for much of the year. A few items, however, should be mentioned to illustrate that nutritive value, or perhaps more correctly, range quality, may be better than indicated by our data. First, we should point out that our analyzed materials included whole plant samples taken above a $2.5-\mathrm{cm}$ stubble. Large herbivores typically harvest diets of higher quality than hand-compounded rations or whole-plant samples by selecting specific plant parts or portions (Kiesling et al. 1969, McInnis and Vavra 1987, Cruz and Ganskopp 1998). That being the case, adequate mineral concentrations in cattle diets probably extend for longer periods of time than suggested by our data. On the downside, however, the actual availability of forage minerals to ruminants also fluctuates seasonally (Peeler 1972).

Second, cattle do forage from a variety of available forages. Early in the growing season cattle may select up to $80 \%$ of their diet from a single grass, but their diets become more diverse as forages mature (Cruz and Ganskopp 1998). Thus a substantial portion of their intake is derived from other sources, and there may be forbs and shrubs available that can also help rectify deitary deficiencies. Clearly, our data show a diversity of grasses can extend the period of adequate nutrition, and some of the less desirable grasses like cheatgrass and Sandberg's bluegrass do furnish excellent early forage and respond to small amounts of precipitation with nutritious vegetative growth late in the season (Figs. 2, 3, and 8). 
Third, there may be natural licks or mineral sources in the area. In some of our intensive, grazing behavior studies at the Northern Great Basin Experimental Range (Cruz and Ganskopp 1998, Ganskopp et al. 1997) we observed instances where cattle ceased grazing and licked bare soil for up to 1 minute. The nutritional value of these events, however, were not quantified. Lastly, livestock have many mechanisms for either conserving, recycling, mobilizing or buffering mineral or nutrient balances within their systems, and these mechanisms allow them to endure short term deficiencies without ill effects (Maynard and Loosli 1969). Again though, lactating animals can not avail themselves of many of these mechanisms (Underwood 1981) when grazing deficient forages.

Addressing a variety of nutritional deficiencies is a vexing problem for producers. In intensively managed pasture, many mineral deficiencies can be rectified by treating the land with a required element or altering $\mathrm{pH}$ of the soil to enhance mineral availability for growing forages (MacPherson 2000). Other options include either oral treatments or injections for stock (Allen and Moore 1983). With largescale feedlot situations, frequent ration sampling and custom supplement formulations may be mixed on even a daily basis to accommodate the dynamics of variable quality in feed supplies.

In most extensive rangeland systems, however, these solutions are economically and/or logistically impossible, and the only recourse is to supply free-access supplements in either block or loose form. MacPherson (2000) suggests these formulations have greatest efficacy if positioned near watering points with 1 station for every 25-40 cows. Conventional wisdom, however, suggest though that rangeland managers should try to disperse their cattle uniformly across pastures by positioning supplements some distance from the areas where their animals typically concentrate (Ares 1953, Bailey and Welling 1999).

Given the logistical demands of ascertaining forage nutritive value and supplement delivery in extensive pastures, ranchers for the most part can not respond to seasonal nutritional dynamics of their forages. Most likely, the best approach is to use a supplement formulation with the ability to rectify all known year-round and potential seasonal deficiencies of their forages. Based on our findings, mineral supplementation is probably more of an issue during what we perceive as good forage years than when plant growth and devel- opment are arrested by drought. McDowell and Valle (2000) list several desirable characteristics of mineral supplement formulations and also warn that mineral excesses are capable of inducing other deficiencies. When formulating mineral supplements for cattle pasturing in the northern sagebrush steppe, we recommend that 8 of the 9 minerals evaluated in this study be added to the mix. These included $\mathrm{Ca}, \mathrm{Mg}, \mathrm{Cu}, \mathrm{P}, \mathrm{K}, \mathrm{Zn}, \mathrm{Mn}$, and $\mathrm{Na}$. Adequate concentrations of iron were available on a year-round basis in all the grasses studied.

\section{Conclusions}

Year-to-year, month-to-month, and species specific patterns of mineral concentrations were quite variable among the 7 northern Great Basin rangeland grasses sampled. Minerals that were deficient on a year-round basis included $\mathrm{Cu}, \mathrm{Zn}$, and $\mathrm{Na}$, and these should of course be additives to any rangeland supplement formulation for beef cattle. Minerals which were seasonally deficient, and in some instances, deficient though out an entire growing season were: $\mathrm{Ca}, \mathrm{Mg}, \mathrm{P}, \mathrm{K}$, and $\mathrm{Mn}$. Month to month patterns among these found low levels of $\mathrm{Ca}, \mathrm{Mg}$, and $\mathrm{Mn}$ early in the growing season with concentrations increasing as forages matured and concentrations declining as plants became weathered and dormant. Phosphorus and K levels were elevated early in the growing season and declined to deficient levels by early July or August. Iron was the only mineral assayed with adequate year-round concentrations in all forages. Contrary to intuitive thinking, mineral concentrations were generally higher among the grasses when soil moisture levels were restricted and plants could not fully advance though their reproductive stages of growth. Shallow rooted grasses like Sandberg's bluegrass, bottlebrush squirreltail, or the winter annual cheatgrass can quickly respond to mid-summer or fall precipitation and furnish additional high quality herbage. Cattle can possibly extend their periods of adequate mineral nutrition by selectively grazing among mixtures of these grasses. We suggest, however, that a mineral supplement be available seasonlong on northern Great Basin rangelands and that the formulation include at least $\mathrm{Ca}, \mathrm{Mg}, \mathrm{P}, \mathrm{K}, \mathrm{Cu}, \mathrm{Zn}, \mathrm{Mn}$, and $\mathrm{Na}$ in available forms and proper ratios.

\section{Literature Cited}

Allen, W.M. and P.R. Moore. 1983. Parenteral methods of trace element supplementation, $\mathrm{p}$. 87-92. In: N.F. Suttle, R.G. Gunn, W.M Allen, K.A. Linklater, and G. Weiner (eds.) Trace elements in animal production and Veterinary Practice. Occasional Pub. of the British Soc. of Anim. Prod., No 7, Edinburgh, Scotland.

Angell, R.F., R.F. Miller, and M.R. Haferkamp. 1990. Variability of crude protein in crested wheatgrass at defined stages of phenology. J. Range Manage. 43:186-189.

AOAC. 1990. Official Methods of Analysis $\left(15^{\text {th }}\right.$ Ed.) Assoc. of Off. Anal. Chem, Washington D.C

Ares, R.N. 1953. Better cattle distribution through the use of meal-salt mix. J. Range Manage. 6:341-346.

Bailey, D.W. and G.R. Welling. 1999. Modification of cattle grazing distribution with dehydrated molasses supplement. J. Range Manage. 52:575-582.

Cruz, R. and D. Ganskopp. 1998. Seasonal preferences of steers for prominent northern Great Basin grasses. J. Range Manage. 51:557-565.

Daubenmire, R. 1970. Steppe vegetation of Washington. Washington Agr. Exp. Sta., College of Agr. Washington State Univ. Bull 62.

Fisher, R.A. 1966. The design of experiments. $8^{\text {th }}$ ed., Hafner, New York.

Flemming, G.A. 1963. Distribution of major and trace elements in some common pasture species. J. Sci. Food and Agr. 14:203-208.

Ganskopp, D. 1988. Defoliation of Thurber needlegrass: herbage and root responses. J. Range Manage. 41:472-476.

Ganskopp, D. and D. Bohnert. 2001. Nutritional dynamics of 7 northern Great Basin grasses. J. Range Manage. 54:640-647.

Ganskopp, D., R. Angell, and J. Rose. 1992. Response of cattle to cured reproductive stems in a caespitose grass. J. Range Manage. 45:401-404.

Ganskopp, D., B. Myers, S. Lambert, and R. Cruz. 1997. Preferences and behavior of cattle grazing 8 varieties of grasses. J. Range Manage. 50:578-586.

Hickman, O.E. 1975. Seasonal trends in the nutritive content of important range forage species near Silver Lake, Oregon. USDA For. Serv. Res. Pap. PNW-187.

Hironaka, M., M.A. Fosberg, and A.H. Winward. 1983. Sagebrush-grass habitat types of southern Idaho. Wildl. and Range Exp. Sta., Univ. of Idaho, Moscow. Bull 35.

Kiesling, H.E., A.B. Nelson, and C. H. Herbel. 1969. Chemical composition of tobosa grass collected by hand-plucking and esophageal-fistulated steers. J. Range Manage. 22:155-159.

Lammond, D.R. 1970. The influence of undernutrition on reproduction in the cow. Animal Breeding Abstracts. 38: 354-372. 
MacPherson, A. 2000. Trace-mineral status of forages, p. 345-371. In: D.I. Givens, E. Owen, R.F.E. Axford, and H.M. Omed (eds.) Forage evaluation in ruminant nutrition. CABI Publishing. New York, N.Y.

Mayland, H.F. and G.E. Shewmaker. 1997. Seasonal changes in forage quality of C-3 grasses on sagebrush grasslands, p. 17-17.. In: B.R. Christie (Chr.) XVII Grassld. Congr. 8-18 June 1997. Winnepeg, Manitoba, and Saskatoon, Saskatchewan Canada. (CDROM).

Mayland, H.F. and F.A. Sneva. 1983. Effect of soil contamination on the mineral composition of forage fertilized with nitrogen. J. Range Manage. 36:286-288.

Mayland, H.F., R.C. Rosenau, and A.R. Florence. 1980. Grazing cow and calf responses to zinc supplementation. J. Anim. Sci. 51:966-974

Maynard, L.A. and J.K. Loosli. 1969. Animal nutrition, $6^{\text {th }}$ ed. McGraw-Hill Book Co., San Francisco, Calif.

McDowell, L.R., G.L. Ellis, and J.H. Conrad. 1984. Mineral supplementation for grazing cattle in tropical regions. World Anim. Rev. 52:1-12.

McDowell, L.R. and G. Valle. 2000. Major minerals in forages, p. 373-397. In: D.I. Givens, E. Owen, R.F.E. Axford, and H.M. Omed (eds.) Forage evaluation in ruminant nutrition. CABI Publishing. New York, N.Y.

McInnis, M.L. and M. Vavra. 1987. Dietary relationships among feral horses, cattle, and pronghorn in southeastern Oregon. J. Range Manage. 40:60-66.
Miller, J.K., and W.J. Miller. 1960. Development of zinc deficiency in Holstein calves fed a purified diet. J. Dairy Sci. 43:1854-1856.

Murray, R. B., H.F. Mayland, and P.J. Van Soest. 1978. Growth and nutritional value to cattle of grasses on cheatgrass range in southern Idaho. USDA For. Ser. Res. Pap. INT-199. Intermountain For. and Range Exp. Sta., Ogden, Utah.

N.O.A.A. (National Oceanic and Atmospheric Administration). 1991-1994. Climatological data annual summary, Oregon 97-100:(13).

NRC. (National Research Council). 1996. Nutrients Requirements of Beef Cattle $\left(7^{\text {th }}\right.$ Ed.). National Academy Press, Washington, D.C

Olson, T.E. 1971. Utilization and supplementation of cheatgrass in southern Idaho. M.S Thesis, Univ. of Idaho. Moscow, Ida.

Peeler, H.T. 1972. Biological availability of nutrients in feeds: availability of major mineral ions. J. Anim. Sci. 35:695-712.

Petersen, R.G. 1985. Design and analysis of experiments. Marcel Dekker, Inc., New York.

Raleigh, R.J. 1988. Joint HVDC Agricultural Study-Final report. Oregon State Univ., Corvallis, Oregon and Dept. of EnergyBonneville Power Administration, Portland, Ore.

Raleigh, R.J. and J.D. Wallace. 1965. Nutritive value of range forage and its effect on animal performance. Research in beef cattle nutrition and management. Special Report 189. Agr. Exp. Sta., Ore. State Univ., Corvallis, Ore.
Sirois, P.K., M.J. Reuter, C.M. Laughlin, and P. J. Lockwood. 1994. A method for determining macro and micro elements in forages and feeds by inductively coupled plasma atomic emission spectrometry. The Spectroscopist 3:6-9.

Sneva, F.A. 1982. Relation of precipitation and temperature with yield of herbaceous plants in eastern Oregon. Int. J. Biometeor. 4:263-276.

Suttle, N.F. 1981. Predicting the effects of molybdenum and sulphur concentrations on the absorbability of copper in grass and forage crops to ruminants. p. 545-548. In J.McC. Howell, J.M. Gawthorne, and C.L. White. (eds.) Trace elements in man and animals - 4. Australian Acad. of Sci., Canberra, Australia.

Turner, H.A. and T. DelCurto. 1991 Nutritional and managerial considerations for range beef cattle production. Beef Cattle Nutr. 7:95-125.

Underwood, E. J. 1981. The mineral nutrition of livestock. Commonwealth Agr. Bureaux, London, $180 \mathrm{p}$.

Vavra, M. and F. Sneva. 1978. Seasonal diets of five ungulates grazing the cold desert biome, p. 435-437. In: D.N. Hyder (ed.) Proc. First Internat. Rangeland Cong., Soc. Range Manage. Denver, Colo.

Vela, N.P., L.K. Olson, and J.A. Caruso. 1993. Elemental speciation with plasma mass spectrometry. Analy. Chem. 65 (13) 585A597A. 